\title{
The mediating influence of liturgy on the way of life - Disposing oppressing powers in oneself and appropriating of compassion towards the other
}

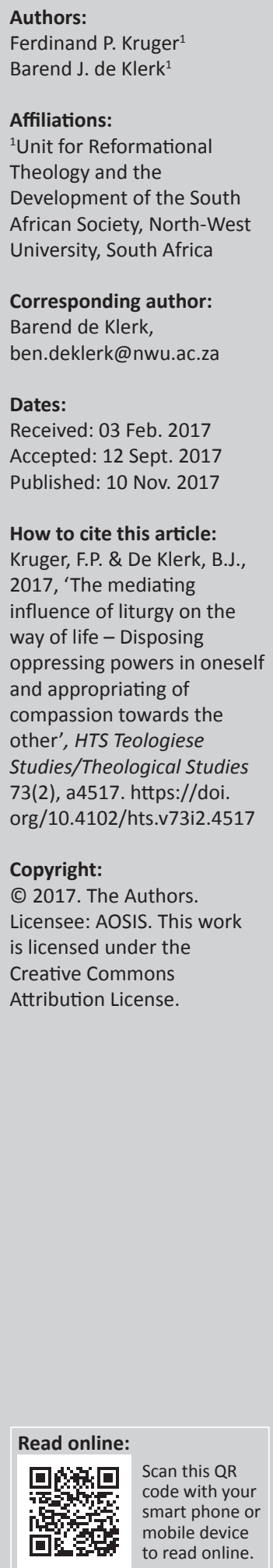

This article presents the authors' research on the mediating functioning of liturgy and its influence on the change of attributions and attitudes. Within a South African context, voices in connection with decolonisation are becoming more audible. This article is not aimed at an evaluation of the positives or negatives of colonisation or decolonisation. It rather intends to show that liturgy can contribute to this debate by helping people to be conscious of their attributions and attitudes regarding other people. In this regard, liturgy can help people to understand their own identity, an identity that is continuously forming and changing in the light of the attitude in the mind of Christ. People have different attributes on societal issues like, inter alia, decolonisation. Liturgy that is concerned with what is happening in society could contribute towards an attitude or attribute change regarding a liturgy of hospitality towards the other. The main research question for this investigation is: In what way does liturgy as a way of life have the potential to influence people's attributes and attitudes regarding breaking free from oppressing powers in oneself towards the other in every sphere of life? The research first presents a qualitative literature review to understand this matter. The authors utilise two of Heitink's phases, namely a hermeneutical understanding of what is happening, and liturgical directives for change. Perspectives from Philippians 2:5-11 are provided to highlight the role of the mind of Christ and of discernment. The article concludes with directives that could possibly influence change regarding attributes and attitudes towards other people.

\section{Introduction}

The decolonial turn, according to Grosfoguel (2007:211), is a dynamic that aims to epistemologically transcend and decolonise the Western canon and epistemology. Within a South African context, the voices of decolonisation become audible when the names of towns, streets and public spaces are challenged; when cases of racism are dealt with publicly and in court; when students protest against visible reminders of the colonial past like with the statue of Cecil John Rhodes on the campus of the University of Cape Town (Snyman 2014:267). Colonialism has ended, but it has left its memories (Sylvester \& Idoko 2014:8). Decolonisation raises new, invasive and intriguing questions regarding embodied human relationships at an interrelated, interpersonal and a communal level in society.

Decolonisation to a certain extent contains a cry of sadness or a sighing voice, something that Cilliers (2015:1) describes as the in-between spaces of paradox. In South Africa, for instance, people are living in a country that has left behind a painful past, but the same country has not yet reached its destination (Cilliers 2015:2). The painful past creates an obstruction for people to experience a meaningful present and future. The voice of decolonisation therefore bears witness of a vivid memory of things in the past that are still remembered (Smit 2008:115). Existential questions regarding identity, responsibility and own attitudes (including biases) about the heritage of the past and engagement in society put people in an awkward reflective position that cannot be avoided. However, decolonisation may also have a deeper meaning of breaking free from oppressing attitudes in oneself towards the underprivileged and towards people currently in a position of power.

In this regard, the importance of a liturgy that is defined as a way of life (cf. Smith 2013:16) emerges. We regard reflection on liturgy as paramount within this particular discourse. Wainwright (1996:92), for example, underlines that history, cultures and liturgy are subject to change. If liturgy is subject to change, it should be accompanied by critical reflection in order not to lapse into mere consumerism. Smit (2008:143) highlights a very important aspect in saying that

Note: This article is published in the section Practical Theology of the Society for Practical Theology in South Africa. 
the identity of a community of believers is at stake in liturgy. The research question could be formulated in the following manner, namely: In what way does liturgy as a way of life have the potential to influence people's attributes and attitudes regarding breaking free from oppressing powers in oneself towards the other in every sphere of life?

This research is interested in the problem of the deep-seated attitudes of people with inborne and historically formed prejudices that may lead to unconscious discrimination. From a liturgical viewpoint, it is strange and lamentable that prejudicial attitudes can persist among committed and worshipping Christians, not only from different cultures, but also within the same culture. In this process, two focal points are juxtaposed, namely people's remembrance of what has happened in the past and the unique remembrance of liturgy. ${ }^{1}$ Liturgy in itself has to do with mediating the tension field between attributes (attitudes) and the radiant light of the Gospel. Liturgy is a compound concept that deals with the wholeness of life that simultaneously offers meaning to people in the midst of problematic realities. People in the midst of challenging realities live at a crossroads and cannot be isolated in liturgical acts from what they experience in daily life.

Heitink (1999:165) uses three keywords in his approach to practical theological research methodology, namely understanding, explanation and change. Three circles are set in motion during research: the hermeneutical circle (with understanding as its keyword), the empirical circle (with explanation as its keyword) and the regulative circle (with change as its keyword). In this research, we were limited to a qualitative literature analysis in which a hermeneutical foundation of the problematic praxis is augmented by liturgical directives for mediating people's attributes in the radiant light of the Gospel.

\section{Hermeneutical understanding of the resilient nature of oppressive powers within oneself \\ Preservation of identity as a propellant for oppressive powers within oneself}

Goudzwaard (1981:39) hits the nail on the head by indicating that ideologies do not arise accidentally, they need injustice or threat to take hold. He added to this viewpoint by underlining the fact that nationalist ideologies make huge gains when a religious element is added (Goudzwaard 1981:40). Nolan (1988:2) argues that preaching the Gospel in South Africa has never been politically neutral. He refers to the fact that the Gospel first came to the shores of South Africa with Dutch and then British colonialism. The colonisers firmly believed that they were bringing civilisation to this part of the world and at the basis of this civilisation was the message of Jesus Christ (Nolan 1988:2). Neither the British,

1.Berger and Spinks (2009:31) highlight the importance of remembrance (recognition) as the work of the Holy Spirit in people so that present, past and future connect. Remembrance within liturgy overarches the tenses of life (cf. Kruger 2016:3). nor the 'boers' in later stages doubted that they were acting according to the Gospel of Jesus Christ and that they were called to Christianise vast areas of the world.

The original preachers of the Gospel in South Africa were of two kinds, namely chaplains and missionaries (Nolan 1988:2). The chaplains ministered to colonial officials, soldiers and settlers. The missionaries came to evangelise the indigenous and colonised people (Nolan 1988:3). They left behind a division between a settler church and a missionary church.

Goudzwaard (1981:40) raises an interesting point when he indicates that the Great Trek of the 1830s was a real flight from the harsh surroundings of British colonialism. The white Afrikaners experienced a threat and this manifested during the Boer War (1899-1902). In such circumstances, it is according to Goudzwaard (1981:41) understandable that maintaining your identity, culture and rights takes on allencompassing significance. It is evident that the legacy of a nation that is accused of colonialism was also deeply affected by colonialism and imperialism. What is at the heart of this? How is it possible that a certain group of people who had been deeply affected by colonialism could later be accused of a similar evil? Certain issues suddenly emerge. One of the burning issues is that preserving identity comes at a price. What is also evident is that preserving of the Afrikaner identity initially emerged from an oath with a very deeprooted religious cognisance. Identity indeed seems to be a very important concept.

In a multicultural society in South Africa where white people form a clear minority, complex legal and political measures soon followed the Boer War to protect the Afrikaner nation (Goudzwaard 1981:42). The unjust system of apartheid was the inevitable result of this attempt to preserve. ${ }^{2}$ It seems like the preservation of identity could become a very dangerous activity, because at the heart of this attempt is the danger of creating some kind of a sanctuary. Within this space or container, nobody is allowed to touch anything, because it should be always the same. From a liturgical and theological viewpoint, this issue raises eyebrows. Goudzwaard (1981:42) indicates that there is always a danger that the Bible can be read selectively so that it can become a handbook for the protection of people's unique identity. Smit (2008:116) addresses the same kind of burning issues, but he is more nuanced in his assumptions. He is also concerned about the possible influence of the Christian faith on aspects such as colonialism, peace and violence. Liturgy could never function in a static or neutral manner. Liturgy could either reflect God as Creator and Redeemer or as something in creation (Beale 2008:16). Beale (2008:21), for instance, underlines the fact that we become what we worship.

People could possibly experience liturgy as observers rather than seeing liturgical actions as dynamic, working powers

2.The concept 'preserve' denotes the following, namely: food made with fruit preserved in sugar, such as jam or marmalade; a sphere, realm or territory of activity regarded as being reserved for a particular person or group; a place, activity regarded as being reserved for a particular person or group; a place,
sanctuary, protected area where game is protected and kept for private hunting or sanctuary, protected area where game is protected and kept for private huntin
shooting; to maintain or protect (something) in its original or existing state. 
that operate within and through participants towards a way of life. This view could offer possibilities for liturgy and ethics to merge. Liturgy is functional in forming the attitudes that transform people's attributes on human dignity and therefore enable people to live together. If liturgy has to do with a way of life that should change, what possibilities could be mediated by means of liturgy?

\section{Liturgy as bridging process}

The relationship between theory and praxis needs mediation (Heitink 1999:168). Mediation has to do with communicative aspects that mediate the Gospel to private life, social establishments and the public sector. In the public sphere, participants rather than escapists are needed. It is evident that the mediation of truth often occurs outside church's immediate sphere of the influence (Heitink 1999:1699). Liturgy has to do with a unique bridging process rather than a third space of observation of what is wrong in society. Liturgical acts that serve as propellants should lead participants to the reality of life so that liturgy becomes a way of life. This mediation bridge should open eyes and provide new possibilities to change attitudes that are still embedded in colonising thought patterns. The bridge of liturgy also offers new insight into the past, because the bridge is open to the past. The same bridge is open to the future, but at the moment participants in liturgy are like stationary vehicles that are slowly but surely bridging the gap between yesterday and tomorrow.

Hauerwas (2002:142) describes the church as God's new mediated language. This all happened with Pentecost, but this new language is simultaneously more than mere words. It is a community whose memory (remembrance) of the Saviour creates the miracle of a people whose very differences contribute to their unity (Hauerwas 2002:149). In the mediating action of liturgy, participants become part of a common history that requires continuous celebration to be rightly remembered. Therefore, the new community of believers has no story to tell. In the telling, they are actually the story being told (Hauerwas 2002:150). The church needs an awareness for the call-and-respond character of God's Word for them to function as a remembering community and to realise what it entails to be a new community among people (Smith 2013:19). In this regard, Louw (2016:14) points in the direction of the compassion (misericordia) needed. $\mathrm{He}$ indicates that this compassion gives meaning or direction to human life. It makes life bearable. Compassion with other people is needed as a theology of the intestines (cf. Louw 2016:14). Compassion means that people from different viewpoints should learn to look through the eyes of other people. This makes liturgy a bridging act receptive to the idea of a vision for the other. Liturgy as an encounter with God and people creates possibilities for meaningful relationships with people in society. It is like one wave that rolls down to another wave.

Liturgy as bridging act has the aim of enabling participants to have compassion for the other (liturgy for the other). Mudge (1998:95) describes this as the calling of the church to have discernment for situational opportunities and voices. Liturgy as bridging process has to mediate the road to the otherness of life. The bridge of liturgy is a very important intersection within the communicative acts between people in society. It could even become dangerous if people ignore the intersection of each other within themselves.

\section{Understanding the functioning of attributes within attitudes towards other people}

The ideal of a liturgy of the otherness is challenged by a tunnel vision caused by underlying attributes. First impressions are lasting when forming possible attitudes regarding other people. Attributes are inferences that people make about the causes of events, the behaviour of others and their own behaviour (Weiten 1992:584). One can formulate it slightly differently and say that people make attributions because they have the need to understand their experiences. It is an attempt to make sense of other people's behaviour and actions (Bergh \& Theron 2006:686). Three important factors should be considered:

- People make attributions when unusual events grab their attention.

- People make attributions when events have personal consequences for them.

- People make attributions when other people behave in unexpected ways.

People tend to locate the cause of behaviour either within a person (personal factors) or outside a person (environmental factors) (Cleary 2010:185). They react quickly with a process of taxonomy when they observe other people (Louw \& Edwards 1998:424). The process of taxonomy entails the evaluation of the personal meaning of what is observed in one's mind. This process occurs instantly. In line with this process of evaluation (good or bad), a next process of attribution is also evident (Bergh \& Theron 2006:130). This process contains attributions of the motives of others. There is a need for attribution because it enables people to predict the future and to exert some influence over events and people.

The distorted view of other people is influenced by a limited insight into the past and future. Therefore, the present realities are often neglected. The difficulty in understanding the process of attribution is that it is guesswork about the causes of events and the behaviour of other people (Weiten 1992:587). Attributional errors and biases lead to inaccurate judgements of whether the cause of behaviour is internal or external (Bergh \& Theron 2006:130).

When people meet each other for the first time, they begin to form impressions of each other right away (Wood \& Wood 1999:571). This process starts early on in people's lives. The influence of opinion formers in children's lives should never be underestimated. It could be their own parents, the social media, friends or events within their environment. People notice obvious attributes first, namely gender, race, age, dress and how physically attractive or unattractive someone is. First impressions (attributions) are important, because they 
are powerful and can colour the later impressions we form about people. It is tragic, but also true that an overall judgement of another person is influenced more by the first information received than by information that comes later (Steinberg 2007:297). Social psychologists describe this as the primary effect. Once an impression has been formed, it provides a framework based on which people interpret later information. Any information that is consistent with the first impression is likely to be accepted and therefore strengthens the impression (Wood \& Wood 1999:571). Expectations about how other persons will act in certain situations influences the way people act themselves. The expectations regarding gender, race, age and ethnic group also influence your attitude, the manner in which you treat other persons and the way you speak about them. The difficulty in evaluating the attributions people make is that people use different measures to evaluate themselves. When they make inferences about themselves, they use the measures of situational attribution and dispositional attribution. In their own mind, they are fully aware of external factors and internal causes (Wood \& Wood 1999:572). In making attributions about other people, people tend to utilise only personal factors and they therefore assume that people from another gender, race and ethnic group have a consistency in behaviour. In short, people have excuses for their own behaviour and thoughts, but they struggle to find excuses for other people's mistakes.

In our discussion regarding the mediating aspect of liturgy, cognisance of the functioning of attributes could be helpful. During the bridging process of liturgy, new perspectives should be opened so that people with colonised and decolonised attributes could experience something of a compassion and willingness to meet other people within the intersection of human communication in society. It is evident that people have attributes regarding worship services, people from other cultures, historical events of the past, political aspects and about people of other races. They evaluate people on the basis of their attributes and attitudes. The challenge from a liturgical viewpoint is to enable people to understand that the voice of decolonisation is more comprehensive than a mere political concept. If liturgy has to do with a way of life, a liturgical view on life should also consider acts that aim to understand and mediate the possibly dehumanising consequences of a colonial past. A liturgy of the other has to start with an honest investigation of one's own attributions, attitudes and perceptions. It also includes the ability to look through the eyes of other people. Liturgy could therefore enable people with a broader framework because of its directedness towards life.

The presence of prejudices towards people of other races is also evident. Louw and Edwards (1998:723) indicate that this kind of prejudices is often based on wrong and inaccurate information regarding other people. Historically speaking, the racial conflict in South Africa originated during the times that the Afrikaner had to struggle to establish their own identity and to acquire land. A new dispensation arrived in 1994 and it seems as if the political change has not succeeded in changing all people's attitudes towards other races (Louw \& Edwards
1998:728). One unique challenge is that people from different cultures and different races are experiencing greater exposure to each other. Psychologists who are advocates of the contact hypothesis assume that prejudices are declining when people are exposed to each other (Bergh \& Theron 2006:196). Liturgy as such could be extremely functional in helping people understand the unique challenges of liturgy as a way of life. In this sense of the word, liturgy serves as a mediator or 'gobetween' where attributes, prejudices and attitudes are not according to the purpose of God.

\section{Understanding the interdependence of liturgy and ethics - lex orandi, lex credendi, lex vivendi}

We have indicated thus far that voices regarding decolonisation are audible and that it influences people's attitudes within society. Liturgy as a way of life has to enable participants in liturgy to become more sensitive to human dignity and to the function of dehumanising powers and ideologies in society. Liturgy as a conveyance of the communication of worship services should claim its unique space within society. The liturgy of the other is an aspect that should be addressed. Liturgy also reckons with the concreteness of life (Smit 2008:165). The interrelatedness between liturgy and ethics should be regarded as important.

Cilliers (2000:19) highlights the fact that preaching without ethics is empty and ethics without preaching is blind. The heading of this section refers to lex orandi, lex credendi. This literally means that the directive of the prayer (worship) is the directive for faith. Smit (2008:137) indicates that the reverse is also true, namely that the directive for faith should also be the directive for worship. This means that critical reflection on liturgy and worship is always needed. Included within the directives for faith is human and ethical behaviour. Therefore, scholars also expanded the concept to lex orandi, lex credendi, lex vivendi [Our prayer (worship) should mark our thoughts and our thoughts should stamp our lives]. Earlier the authors referred to the importance of remembrance. We now take up that line of thought. Remembrance (anamnesis) lies in the heart of liturgy. It is about remembrance of who God is, who humans are and what life really is (Smit 2008:141). This very idea of remembrance is simultaneously functional in identity forming (Hauerwas 2002:347; Gill 1999:233). In the togetherness of participants in liturgy, people explore their identity and the meaning of life (Smit 2008:141). The concept of remembrance is evident in all the various liturgical elements. True identity is founded on the remembrance of God's presence in all spheres of human life. Any kind of liturgical change should be responsible and should always consider the identity of the people worshipping.

Smit (2008:144) highlights a very important aspect, namely that the communication of liturgy and participation in liturgy also influence people's religious beliefs. The meaning of life and liturgy are closely linked to each other. Atkins (2004:13) indicates that the process of remembrance is functional in shaping the events of the past and the present. It also determines people's view of the future. The content of what 
people remember also influences their view on reality. Anything that people could translate into words and concepts enables them to recall its essence. Liturgical language acts like a trigger for people's memories and can be compared with the bar code of a product for sale. Words recall remembrance (Atkins 2004:21).

Liturgy always challenges the realities in life in a prophetic manner, namely: attitudes, culture, ideologies, political realities, economical injustices and aspects that influence human dignity (Smit 2008:144). When realities change, like most things in life, liturgy should be functional in mediating the challenges in light of what is remembered. The anchor is God's presence and the fact that He utilises worship services to send His children back to the world to live in a creative and new manner. Liturgy should connect with human life (ethics), because people's identity is at stake. Any attitude, attribute or behaviour that is contradictory to the identity believers have in Christ should also be questioned. Liturgy (worship) is an act that matters, because our liturgy in Christ also influences our view on other human beings. Liturgy is also the guide or directory to human life (Smit 2008:148). It is indeed an important act because in worship services, people are together in the presence of God. Therefore, liturgy offers a communal and pastoral space for participants to serve God, each other and the world (De Klerk \& Leuschner 2003:441). The worship service is central to people's lives. Liturgy is therefore functional in shaping three kinds of relationships, namely people's relationship (identity) with God, with other believers and with the world (De Klerk \& Leuschner 2003:445).

The way an individual views life matters, because worship services also create new possibilities regarding koinonia [community] (Smit 2008:148). Therefore, liturgy should guide people to comprehend that living with each other is also a touchstone for the things they are remembering during worship services. Worship services should therefore have an open vision on community as such (Smit 2008:149). Ethics supports Practical Theology with its vision for life and the proper attitude with which to regard life. Liturgy could be functional in helping participants to see and hear reality of life differently. Therefore, liturgy could enable people to understand that certain things should be unlearned, while other things must be learned (Smit 2008:155). Liturgy could be functional within this movement of turn-and-learn.

Tolerance, for instance, becomes a very important concept and it involves the willingness to accept differences (religious, moral, ethnic or economical). In the context of people who are raising voices in favour of decolonisation and people who are still in the midst of colonial thinking, the issue of how one should act in the midst of differences is a burning topical point. The issue is how a person should relate with other persons with which he or she disagrees (Bretherton 2010:123).

The concept of hospitality rather than hostility could be regarded as the most suitable way to address relations with those with whom you disagree (Bretherton 2010:123). The philosopher Kant once indicated that the virtue of misericordia is central to the proper functioning of any society (cf. Bretherton 2010:127; Louw 2016:12). Misericordia denotes the capacity for grief or sorrow over someone else's distress just insofar as one understands the other's distress as one's own (Bretherton 2010:127). It could be called sentiment that is guided by reason. Therefore, misericordia directs one to include strangers (people from different backgrounds) within one's communal relationships and therefore an expansion of one's communal obligations should take place (Bretherton 2010:127). A liturgy of the other or a liturgy of hospitality encapsulates the importance of the community of believers' relationship with its neighbours. Liturgy is focused on enabling people to engage in the lives of those around them. Mediating possible differences is, liturgically spoken, never simply a question of people accommodating each other's views, nor of a compromise between two positions, nor a rivalry where one seeks to vindicate one's view against the answer given by other people (Bretherton 2010:151). Real discernment is rather at stake, discernment regarding the truth of what God wants His children to be in this world. According to the authors, the liturgy of hospitality directs each participant in liturgy to communication and conversation with its neighbours, a liturgy that leads to the action of living or having one's being in and among one's neighbours (Bretherton 2010:151). The expressions lex orandi, lex credendi and lex vivendi open up a dynamic vision of the relationship between liturgy and ethics.

\section{Understanding discernment as the opposite of a preserving attitude}

Thus far, we have indicated that a preserving identity attitude within relationships creates tension fields between people (see 'Preservation of identity as a propellant for oppressive powers within oneself' section). Furthermore, a mediating and bridging act of liturgy (section 'Liturgy as bridging process') is needed to address attributes (section 'Understanding the functioning of attributes within attitudes towards other people') that divide people in society. Liturgy has the bridging power to open people's eyes to a renewed way of life (section 'Understanding the interdependence of liturgy and ethics - lex orandi, lex credendi, lex vivendi'). A refined attribute of discernment mediated through liturgy that includes an ethical outlook and behaviour towards the other is very much needed within a South African context. Discernment involves with the mind of Christ rather than a cosmetic thought pattern (see the following section). Liturgy has to evoke an awareness of community and energise a willingness to act as community of believers each and every day of the week (Schlafer \& Sedgwick 2007:8).

\section{Understanding the concept of Фpovnoic - Philippians 2:5}

The paranetic section of Philippians 2:1-4 is closely linked with Philippians 2:6-11 by means of Philippians 2:5 (Smit 1995:180). The following words appear in Philippians 2:5,

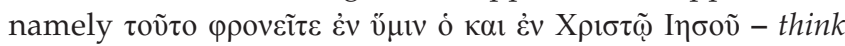
about that what (the mind that) you have in Christ Jesus. The question is what kind of verb must be assumed in the last part of this sentence. The formula 'in Christ Jesus' is 
important, because that gives an indication that verse 5 should be understood as a directive to have the same attitude (mind) as people that are in Jesus Christ (Smit 1995:182). Louw and Nida (1993:259) indicate that the

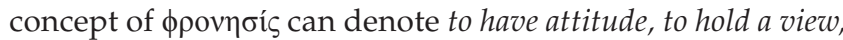
thoughtful planning or wisdom. The concept of careful planning and wisdom in human acts offers the insight that communication should deal with the mind of Christ, which should be evident in human speech. Philippians 2:5 shows the like-mindedness that believers in Christ should have. Believers should attune their attitude to the humble mind of Jesus Christ and should take such a view of life (Manser 2010:2136). The wisdom of phronesis as attitude should therefore be the driving force behind the actions of religious communities (Louw 2015:62). Brown (1986:616) indicates that the concept of $\phi \rho o v \eta \sigma i s$ [mind of Christ] denotes the idea of discernment and judicious insight into the essence of attitudes. When one has the mind of Christ, this attitude determines the functioning and the focus of liturgy. Liturgy should open a new vision of what is expected in life, but what kind of vision?

Philippians 2:5-6a gives a directive regarding liturgy as a way of life. The followers of Christ should have the same mindset (attitude) because we are made in God's image. Janson (2003:96-97) finds the choice to use $\mu о \rho \varphi \tilde{n}$ very interesting. This concept refers to the fact that Christ was really God. Although he was truly God, he took the form of bondservant and became a man. The concept of $\mu о \rho \varphi \tilde{n}$ is used again. Jesus fully embraced being a man. In becoming a man, hHe literally emptied himself. He came to serve as a man and not God (Phlp 2:6). The concept of $\dot{\alpha} \rho \pi \alpha \gamma \mu$ òv is striking in this context. This concept denotes something of a predator stalking its prey. Jesus did not act like a predator (Janson 2003:99). The same mindset or attitude of Christ should be part of believers' lives. People should learn to be followers and not predators of one another. This is also true within the framework of this discussion. Discernment according to the principle of the mindset of Christ liberates people from becoming predators because of a certain ideology. Discernment also includes the idea of including other people within your discernment. Therefore, discernment is interested in wisdom within human relationships.

Louw (2015:64) therefore indicates that the concept of

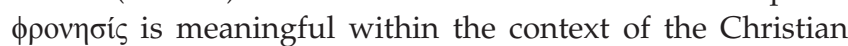
faith, which deals with the issue of wisdom as the driving force behind the actions of religious communities. Phronesis is not a mere intellectual concept. Wisdom is to understand the mind of Christ (to be his followers), having insight into what is right for daily life, what the driving force behind decisions is, sober judgement according the living faith and the quest for wisdom in church and society. A person's renewed mind, which is capable of discerning God's will, is the driving force in the evaluation of the self and of the person's real identity (Stott 1994:325). The renewed mind is indicative of the sober self-image or a humble mind like Christ's (Frangipane 2013:13; Moo 2002:180). The dehumanising acts of the predator who becomes a coloniser of people's minds and lives are simply contradictory to likemindedness to Christ.

\section{Hermeneutical implications of understanding the oppressive powers within oneself and the mediating function of liturgy}

1. It is important in the understanding of the present praxis to deal with the power of 'remembering'. Although the argument could be that colonisation is something of the past, the pain and anger as result of the injustices of the past still live in the mind and memories of the other.

2. Two focal points are juxtaposed, namely people's remembrance of what has happened in the past and the unique remembrance of liturgy.

3. The possibility that inborne and historically formed prejudices may lead to urges in oneself to oppress the other should lead to self-examination in light of the truth of the Gospel. In the process of self-examination, serious care should be taken not to use the Bible as a handbook for protection of one's identity. A liturgy of the other has to start with an honest investigation of one's own attributions, attitudes and perceptions.

4. Liturgy is always connected with one's identity, because worshippers become what they worship. Therefore, liturgy has the potential to influence people because it functions in the tension field between attributes and attitudes and the light that the Gospel projects in the worshipper.

5. The power of liturgy could be undermined if the worshipper is a sort of observer and spectator who wants to be entertained and who is not wholeheartedly involved in the acts of liturgy. This could be described as escape rather than engaging in liturgical acts.

6. Liturgy has to do with a bridging process between celebrating God's presence and great acts and the praxis of everyday life. It should lead participants to the reality of life so that liturgy becomes a way of life. Liturgy should be considered as a dynamic mediating act that infiltrates possible tension fields.

7. The mediating bridge of liturgy opens eyes and provides new possibilities to change the attitudes of oppressive powers and one's own colonising nature. The change is especially from an attitude cognisant of the power to oppress to an attitude of compassion. This entails among other things looking through the eyes of other people to the past, future and the tensions of the present.

8. The ideal of a liturgy of the other is challenged by a tunnel vision caused by underlying attributes. First impressions (attributions) are important, because they are powerful and can colour the later impressions we form about people. The distorted view of other people is influenced by a limited insight into the past and future. Therefore, the present realities are often neglected.

9. The challenge from a liturgical viewpoint is to enable people to understand that the voice of decolonisation is more comprehensive than a mere political concept. In the bridging process of liturgy, new perspectives should be opened so that people with both colonised and 
decolonised attributes could experience something of the compassion and willingness to meet each other within the intersection of human communication in society. Liturgy serves as a mediator or 'go-in between' where attributes, prejudices and attitudes are not according to the purpose of God.

10. Remembrance (anamnesis) lies at the heart of liturgy. It is about remembrance of who God is, who humans are and what life really is and it is simultaneously functional in identity formation. In the togetherness of participants in liturgy, people explore their identity and the meaning of life. The concept of remembrance is evident in all the various liturgical elements. True identity is founded on the remembrance of God's presence in all spheres of human life. Any kind of liturgical change should reckon with the identity of people worshipping.

11. Liturgy always challenges realities in life in a prophetic manner. This includes things like attitudes, culture, ideologies, political realities, economical injustices and aspects that influence human dignity. The norm is God's presence and the fact that He utilises worship services to send His children back to the world to live in a creative and new manner. Liturgy should connect with human life (ethics), because people's identity is at stake. Any attitude, attribute of behaviour that is contradictory to the identity believers have in Christ, should also be questioned.

12. Liturgy could be functional in helping participants to see and hear the reality of life differently. Therefore, liturgy could enable people to understand that certain things should be unlearned, while other things must be learned. Liturgy could be functional within this movement of turn-and-learn.

13. Liturgy is aimed at enabling people to engage in the lives of those around them. Mediating possible differences is, liturgically spoken, never simply a question of people accommodating each other's views, nor of a compromise between two positions, nor of rivalry as one's view seeks to vindicate itself against the answer given by other people. Real discernment is rather at stake, discernment regarding the truth of what God wants His children to be in this world.

14. Because Christ is the centre of all liturgical acts, it is important that believers in Christ should have likemindedness ( $\phi \rho o v \eta \sigma i s$ attitude) of Christ. They should attune their attitude to the humble mind of Jesus Christ and should take such a view of life.

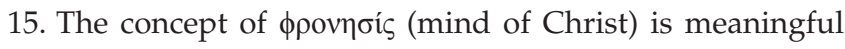
within the context of the Christian faith and worshipping, which deals with the issue of wisdom as the driving force behind the actions of religious communities, also liturgical acts. Wisdom is to understand the mind of Christ (to be His followers), having insight into what is right for daily life, what the driving force behind decisions is, sober judgement according the living faith and the quest for wisdom in church and society.

16. The concept of $\phi p o v \eta \sigma i \varsigma$ denotes the idea of discernment and judicious insight into the essence of the functioning of attitudes. To have the mind of Christ determines the functioning and the focus of liturgy. Liturgy should open a new vision of what is expected in life.

\section{Liturgical perspectives regarding attitude change}

The previous section indicates that the hermeneutical circle of understanding offers five important aspects that should be elaborated further, namely: liturgy as mediating act (bridging), liturgy of the other, liturgy and its connectivity with ethics, liturgy and hospitality and directives for change.

Liturgy as a way of life has the potential to influence one's attributes and attitudes through a cycle of actions.

\section{Liturgy should act in a mediating and bridging manner}

Liturgy as bridging concept offers an appropriate manner of communication between two places that would otherwise be cut off from one another by a gulf of misunderstandings. Liturgy as a communicative act offers possibilities regarding the flow of traffic in human communication within a South African context that is based on attributes and attitudes. First impressions in people's lives are lasting and have negative consequences for the manner people address each other in society. Liturgy entails bridging a chasm not only between God's Word and reality, but also between the transforming work of the Spirit and oppressing powers within oneself and in community (cf. Stott 1994:138). The mediating thrust of the Gospel in the midst of realities in society should never be underestimated. The mediating power of liturgy has to do with communication of the unchanged Gospel and its view on life to an ever-changing society in which the sighs because of oppressing powers are audible. For liturgy as bridging act to function properly in mediating the Gospel, it is important to be anchored properly on both sides of the chasm. This includes that the radiant light of the Gospel is not compromised, but on the other hand, liturgy does not ignore the context in which it is functioning.

Liturgical acts, such as appropriating the message of the Word, experiencing the mind of Christ in the sacraments, praying, singing and receiving blessings, develop compassion and make liturgy a bridging act receptive for a vision for the other.

\section{Liturgy should focus on the other}

In the bridging process of liturgy, new perspectives should be created for people with colonised and decolonised attributes so that they can experience something of the compassion and willingness to meet people within the intersection of human communication in society. Liturgy that mediates at the same time leads to the awareness of other people in daily life. The concept of discernment, like-mindedness with Christ, because he is living in us, should provide direction for the way the community of believers look at their own attitudes, attributes and perceptions regarding other people in society. 
Discernment in society has to do with the fact that believers have something in common with this world. A liturgy of the other enables people to think less of themselves (not about yourself) and to think more about other people.

A liturgy of the other has to start with an honest investigation of one's own attributions, attitudes and perceptions. Liturgy serves as a mediator or 'go-between' where attributes, prejudices and attitudes are not according to the purpose of God. Therefore, liturgy should also guide people so that they comprehend that living with each other is also a touchstone for the things they are remembering during worship services.

Liturgy is anchored in the dynamic power of the Holy Spirit and this should enable it to expose a community of believers' deepest attributes and attitudes against other people. It should also ignite a communal cognisance of the presence of the living God. Liturgy should function as a lens so that we have a clear view of the sighs and needs of the other. The mind of Christ is the pupil of the eye of liturgy. Without this aspect, liturgy will struggle to enable a community of believers to really see the pain and suffering of other people as a result of oppression.

\section{Liturgy should be closely connected with life (ethics)}

Liturgy as bridging concept is concerned with relating the Gospel to the world. It could not be denied that the Gospel always has ethical implications and ethics is concerned with correct attitudes towards life and the viewpoints of other people.

Therefore, the mind of Christ should be regarded as important in enabling people to think ethically and responsibly about other people and societal challenges. The domains of Liturgics and Ethics complement each other regarding the message of obedience to God. The Word of God requests an act of obedience from hearers and the concept of obedience implies the manner in which hearers of the Word of God appropriate the grace of God for themselves.

Sharpening the ethical dimension entails creating a clear vision of the profoundness, beauty and lasting effect of acts of righteousness that flow from a restored relationship with the graceful God. Liturgy has everything to do with the formation of people's identity according to God's will. After tasting the righteousness of the kingdom of God, the unbearableness of prevailing unrighteousness in society comes sharply and painfully into focus and liturgy cannot ignore this kind of reality in a disobedient manner.

Liturgy as a way of life has to enable participants in liturgy to become more sensitive to human dignity and to dehumanising powers and ideologies in society. Every worship service has to be open towards society. Being blessed by liturgy entails being a blessing to other people in daily life. All the elements of liturgy during worship services should focus on the liturgy of life and therefore liturgy should reach out to the world. It should simultaneously interact with the power of the Gospel and the participation of the community of believers through the Holy Spirit, without a legalistic appeal to obedience.

\section{Liturgy should focus on hospitality on the crossroads with attributes and attitudes}

Liturgy takes people to crossroads in their lives. In a hostile society suffering because of the resilient nature of attributes and attitudes, one has to ask what could possibly be done to mediate values that will enrich dignity.

Liturgists and participants in liturgy should always be aware of the fact that their own attitudes can easily be the product of the influence of the media or even of opinion formers. The impact of social media and the Internet on the formation of people's attitudes and attributions is a reality. People listen to sermons and participate in liturgy with intrinsic attributes, perceptions and attitudes that are foreign to the language they hear in worship services. It stimulates what is often called cognitive dissonance, and cognitive dissonance creates awkwardness in people's lives because of two sets of information or communication that appeal to them. The abstinence of attitudes, attributes and perceptions requires a long-suffering attitude from liturgists and participants in liturgy.

A liturgy of compassion and hospitality offers new entrances to renewed relationships between communities. It could be liturgically mediated by a renewed focus on care for the sick and the poor, hospitality to strangers, hospitality towards people with different viewpoints and religious backgrounds, peace-making endeavours within relationships between communities and bigger awareness of societal realities. In indicating this, we assume that liturgy rather than preaching alone should always indicate that liturgy should continue in daily life. Liturgy should not create the impression of people who are trying to escape from realities, but rather of people who are coming together as a community to be a truthful community of believers in daily life. A new kind of attitude is being formed, an attitude that regards hospitality towards other people as paramount.

The liturgy of hospitality directs each participant to the liturgy to communication and conversation with his or her neighbours. It is a liturgy that leads to actions of living or having one's being in and among one's neighbours.

\section{Liturgy should be a changing liturgy that forges life-change}

Any worship service in which the focus is not on true communion with Christ will sooner or later deteriorate into a general human exercise. But it should also be said that communio cum Christo and real mediation with Christ are provided by Word and Spirit. Without the dynamic power of the Spirit, liturgy will be powerless and insufficient in giving perspective on the wholeness of life. God's presence could not be created through a liturgist's technique of 'do-it-yourself', and therefore believers should attune their attitude to the humble mind of Jesus Christ and should take such a view of life. 
Liturgy that reckons with the underlying functioning of people's attributes and attitudes regarding other people could therefore be functional in mediating the alternative in a way of life towards other people. Liturgy has to do with life as such. Worship services are not static events, but rather dynamic encounters with God and with each other. Liturgy during worship services should mediate God's radiant Gospel and especially the like-mindedness with Christ in order to address the underlying functioning of attributes and attitudes. Liturgy should also connect with ethics in order to edify people as a body of Christ and a community of believers that cares for a communal identity for other people.

Liturgical acts should challenge life in a prophetic manner. This should be kept in mind when structuring the liturgy. Liturgy could enable people to understand that certain things should be unlearned, while other things must be learned. It can be functional within this movement of turn-and-learn. Discernment according to the principle of the mindset of Christ liberates people from staying or becoming 'colonisers' because of a certain ideology. Discernment also includes the idea of including other people within your discernment. Therefore, discernment is interested in wisdom within human relationships.

In the cycle of these processes of liturgy, new perspectives should be opened so that people with colonised and decolonised attributes can experience something of the compassion and willingness to meet other people within the intersection of human communication in society.

\section{Conclusion}

In this article, the authors indicated the importance of the expression lex orandi, lex credendi, lex vivendi. The vantagepoint in highlighting the importance of liturgy for daily life was the mediating power of liturgy itself. Liturgy is taking people to familiar and also to unfamiliar spaces in their lives with the commitment of a renewed attitude. Within this process, the importance of recognition is regarded as pivotal. The mediating influence of liturgy is also aiming to daily life and to the importance of ethics. Liturgy, therefore, should enable participants in liturgy to regard and to see life differently. Therefore, liturgy enables participants to realize the fullness of being among other people in society. A new kind of cognition, namely the wisdom of the mind of Christ should be evident. Liturgy is indeed a bridging act receptive for a vision of the other. Within a South African context, possibilities regarding a liturgy of hospitality becomes a reality that also influences people's attributes regarding colonised and decolonised thought patterns.

\section{Acknowledgements Competing interests}

The authors declare that they have no financial or personal relationships which may have inappropriately influenced them in writing this article.

\section{Authors' contributions}

Both authors equally contributed to the research and writing of this article.

\section{References}

Atkins, P., 2004, Memory and liturgy. The place of memory in the composition and practice of liturgy, Ashgate, London.

Beale, G.K., 2008, We become what we worship. A Biblical theology of idolatry, Apollos, Nottingham.

Berger, T. \& Spinks, B.D., 2009, The Spirit in worship - Worship in the Spirit, Liturgical Press, Minneapolis, MN.

Bergh, Z. \& Theron, A., 2006, Psychology in the work context, Oxford University Press, Cape Town.

Bretherton, L., 2010, Hospitality as holiness. Christian witness amid moral diversity, Ashgate, London.

Brown, C., 1986, 'Phronesis', in L. Coenen, E. Beyreuther \& H. Bietenhard (eds.), The New International Dictionary of the New Testament Theology III, p. 616, Zondervan, Grand Rapids, MI.

Cilliers, J., 2000, Die genade van gehoorsaamheid, Lux Verbi, Kaapstad.

Cilliers, J., 2015, 'Seeing, sighing, signing contours of a vulnerable homiletic', paper presented at the Societas Homiletica, Stellenbosch, Cape Town.

Cleary, S., 2010, The communications handbook, Juta, Landsdowne.

De Klerk, B.J. \& Leuschner, F.W., 2003, 'Die erediens as instrument in gemeentebou toegespits op die Gereformeerde kerke in Suid-Afrika', In die Skriflig 37(3), 439-459.

Frangipane, F., 2013, Spiritual discernment and the mind of Christ, Arrow, New York.

Gill, R., 1999, Churchgoing and Christian ethics, Cambridge University Press, Cambridge.

Goudzwaard, B., 1981, Idols of our time, Inter-Varsity Press, Downers Grove, IL.

Grosfoguel, R., 2007, 'The epistemic decolonial turn. Beyond political-economy paradigms', Cultural Studies 21(2\&3), 211-223. https://doi.org/10.1080/0950 2380601162514

Hauerwas, S., 2002, The Hauerwas reader, Duke University Press, London.

Heitink, G., 1999, Practical theology, Eerdmans, Grand Rapids, MI.

Janson, M., 2003, Heerlikhede uit die Skrif. 'n Bundel van vreugde en verwondering oor die grootheid en genade die Here en sy Woord, Christelike Uitgewersmaatskappy, Vereeniging.

Kruger, F.P., 2016, 'n Praktiese-teologiese ondersoek na prediking en die effek van sosiale kognisie in die handeling van kontekstualisering', In die Skriflig 50(1), Art. \#2006, 1-11. https://doi.org/10.4102/ids.v50i1.2006

Louw, D. \& Edwards, D., 1998, Sielkunde. 'n Inleiding vir studente in Suider-Afrika, Heinemann Continued Education, Louisville, KY.

Louw, D.J., 2015, Academic theology: Between sapientia (wisdom) and scientia (science). Theory formation in practical theology, University of Stellenbosch, Stellenbosch.

Louw, D.J., 2016, 'Politics of democracy or policy of embracement?', paper presented in Potchefstroom, Potchefstroom, North West.

Louw, J.P. \& Nida, E.A., 1989, Greek English lexicon of the New Testament (I), United Bible Studies, New York.

Louw, J.P., \& Nida, E.A., 1993, Greek English lexicon of the New Testament (I), United Bible Studies, New York.

Manser, M.H., 2010, The New Matthew Henry Commentary, Zondervan, Grand Rapids, MI. Moo, D.J., 2002, Encountering the book of Romans, Baker, Grand Rapids, MI.

Mudge, L.S., 1998, The church as moral community, Continuum, New York.

Nolan, A., 1988, God in South Africa, Clyson, Cape Town.

Schlafer, D.J. \& Sedgwick, T.F., 2007, Preaching what we practice. Proclamation and moral discernment, Morehouse Publishing, Pennsylvania, PA.

Smit, A., 1995, 'Nuut gedink oor leierskap in gemeentes', in C. Burger, J. Hendriks, M. Van der Merwe \& A. Smit (eds.), Gemeente en bediening. Nuut gedink oor leierskap in gemeentes. Die begeleiding van 'n christelike gemeenskap, pp. 16-36, Lux Verbi, Kaapstad.

Smit, D.J., 2008, Geloof en openbare lewe, Sun Press, Stellenbosch.

Smith, J.K.A., 2013, Liturgy as a way of life. Embodying the arts in Christian worship, Baker, Grand Rapids MI.

Snyman, G., 2014, 'Responding to the decolonial turn: Epistemic vulnerability', In Missionalia 43(3), 266-291. https://doi.org/10.7832/43-3-77

Steinberg, S., 2007, An introduction to communication studies, Juta, Cape Town.

Stott, R.J.W., 1994, New issues facing Christians today, Zondervan, Grand Rapids, MI.

Sylvester, O.A. \& Idoko, O., 2014, 'Decolonisation in Africa and Pan-Africanism', Yönetim Bilimleri Dergisi 12(23), 7-31.

Wainwright, G., 1996, 'Renewing worship, the recovery of classical patterns', Worship with One Accord 4(1), 127-140.

Weiten, W., 1992, Psychology: Themes and variations, Brooks \& Cole, CA.

Wood, S.E. \& Wood, E.G., 1999, The world psychology, Allyn \& Bacon, Boston, MA. 